\title{
High Efficiency of Dye-Sensitized Solar Cells Based on Ruthenium and Metal-Free Dyes
}

\author{
Che-Lung Lee, ${ }^{1}$ Wen-Hsi Lee, ${ }^{1}$ and Cheng-Hsien Yang ${ }^{2}$ \\ ${ }^{1}$ Department of Electrical Engineering, Nation Cheng Kung University, No. 1, Daxue Rd., East Dist., Tainan City 70101, Taiwan \\ ${ }^{2}$ Nano-Powder and Thin Film Technology Center, ITRI South, Room 603, Buildig. R2, No. 31, Gongye 2nd Road, Annan District, \\ Tainan 70955, Taiwan
}

Correspondence should be addressed to Cheng-Hsien Yang; jasonyang@fusol-material.com

Received 8 September 2013; Accepted 12 October 2013

Academic Editor: Teen-Hang Meen

Copyright (C) 2013 Che-Lung Lee et al. This is an open access article distributed under the Creative Commons Attribution License, which permits unrestricted use, distribution, and reproduction in any medium, provided the original work is properly cited.

\begin{abstract}
The influence of using different concentrations of triazoloisoquinoline based small molecule as coadsorbent to modify the monolayer of $\mathrm{a} \mathrm{TiO}_{2}$ semiconductor on the performance of a dye-sensitized solar cell is studied. The co-adsorbent significantly enhances the open-circuit photovoltage $\left(V_{\text {oc }}\right)$, the short circuit photocurrent density $\left(J_{s c}\right)$ the solar energy conversion efficiency $(>\eta)$. The co-adsorbent $4 \mathrm{~L}$ is applied successfully to prepare an insulating molecular layer with N719 and achieve high energy conversion efficiency as high as $8.83 \%$ at $100 \mathrm{~mW} \mathrm{~cm}^{-2}$ and AM 1.5 at 1 to 0.25 (N719: co-adsorbent) molar ratio. The resulting efficiency is about $6 \%$ higher than that of a nonadditive device. The result shows that the organic small molecule $4 \mathrm{~L}$ (2-cyano3-(5-(4-(3-oxo-[1,2,4] triazolo[3,4-a]isoquinoline-2(3H)-yl)phenyl)thiophene-2-yl)acrylic acid) is the promising candidates for improvement of the performance of dye-sensitized solar cell.
\end{abstract}

\section{Introduction}

Dye-sensitized solar cells have attracted considerable academic and industrial research interest since Regan and Grätzel's report in 1991 [1]. Usually these cells consist of a working electrode which is coated with a dye-sensitized mesoporous film of nanocrystalline particles of $\mathrm{TiO}_{2}$, a Ptcoated counterelectrode, and an electrolyte containing a suitable redox couple. The function of such devices is based on the electron injection from the photoexcited state of the dye molecule into the conduction band of the $\mathrm{TiO}_{2}$, followed by regeneration of the dye by an iodide/triiodide redox couple. Typically, high power conversion efficiencies $(\eta)$ of more than $11 \%$ have been achieved by using ruthenium complex and acetonitrile based electrolytes [2]. However, organic additives play a key role in the characteristics of both electrolytes and devices and have been explored extensively with regard to improving the efficiency of DSSC [3-5].

A few reports have described the use of organic additives for a compact layer, comprised of the dye and coadsorbent
$[6,7]$. Chenodeoxycholic acid (DCA) is frequently added to the dye solution to enhance the open-circuit photovoltage $\left(V_{\mathrm{oc}}\right)$, the short circuit photocurrent density $\left(J_{\mathrm{sc}}\right)$, and the efficiency $(\eta)$ of DSSC $[8,9]$. The $V_{\mathrm{oc}}, J_{\mathrm{sc}}$, and FF of the DSSC are affected by DCA due to the suppression of dark current at the semiconductor/electrolyte junction, since DCA blocks the surface states $\mathrm{Ti}(\mathrm{IV})$ ions that are active in the charge transfer [10]. Due to the insulating molecular layer, the charge recombination process can be shielded, and this increases the $V_{\mathrm{oc}}, J_{\mathrm{sc}}$, and $\eta$. Several approaches have been developed for this purpose, such as the use of pyridinium additives [11], pyrimidine additives [12], dipolar carboxylic acid derivatives [13], zwitterionic coadsorbents [14], and guanidinium cations [4]. In this paper, we synthesize a new triazoloisoquinolinebased organic small molecule used as co-adsorbents to modify the monolayer of a $\mathrm{TiO}_{2}$ semiconductor. We discuss the concentration effect of co-adsorbents and investigate the possibility of using triazoloisoquinoline-based organic small molecule as co-adsorbents in DSSC. 


\section{Experimental}

2.1. General Procedure for Preparation of Solar Cells. Fluorine-doped tin oxide (FTO, $10 \Omega$ square $^{-1}$ ) glass plates were cleaned using detergent solution, water, and ethanol in an ultrasonic bath overnight. The screen-printing procedure was repeated with $\mathrm{TiO}_{2}$ paste $(\sim 15-20 \mathrm{~nm}$ colloidal particles, Ti-Nanoxide T series, Solaronix SA) to obtain a transparent nanocrystalline film of thickness around $12 \mu \mathrm{m}$. The $100 \mathrm{~nm}$ colloidal particles were prepared in a basic environment according to the literature [15] and dispersed in $\alpha$-terpineol with ethyl cellulose for scattering $\mathrm{TiO}_{2}$ paste. A scattering layer around $4 \mu \mathrm{m}$ was deposited by using this scattering $\mathrm{TiO}_{2}$ paste and a final thickness of $16 \mu \mathrm{m}$ was attained. The $\mathrm{TiO}_{2}$ electrodes were gradually annealed at $450^{\circ} \mathrm{C}$ for $30 \mathrm{~min}$ in an oven in an air atmosphere. After sintering, the electrodes were further treated with $0.2 \mathrm{M} \mathrm{TiCl}_{4}$ aqueous solution at room temperature for $12 \mathrm{~h}$, then washed with water and ethanol, and annealed at $450^{\circ} \mathrm{C}$ for $30 \mathrm{~min}$. When the temperature decreased to $70^{\circ} \mathrm{C}$ after sintering, the electrodes were immersed into dye solution, which included $0.5 \mathrm{mM} \mathrm{N719}$ and different concentrations of co-adsorbent in tert-butanol/acetonitrile (AN) (1:1 in volume). The dye solutions were kept at $25^{\circ} \mathrm{C}$ for more than $18 \mathrm{~h}$ to allow the dye to adsorb to the $\mathrm{TiO}_{2}$ surface. After the adsorption of the dyes, the electrode was rinsed with the same solvent. The dye-loaded $\mathrm{TiO}_{2}$ film as the working electrode and Pt-coated TCO as the counterelectrode (about $20 \mathrm{~nm}$ ) were separated by a hot-melt Surlyn sheet $(25 \mu \mathrm{m})$ and sealed together by pressing them under heat. The electrolytes were introduced into the gap between the working and counterelectrodes from two holes predrilled on the back of the counterelectrode. Finally, the two holes were sealed with a Surlyn film covering a thin glass slide under heat. The cells were evaluated by using $0.6 \mathrm{M}$ [BMI][I], $0.1 \mathrm{M}$ GuNCS, $0.3 \mathrm{M}$ $\mathrm{I}_{2}$, and $0.5 \mathrm{M} \mathrm{TBP}$ in a AN/VN $(85 / 15, \mathrm{v} / \mathrm{v})$ solvent as the redox electrolyte.

2.2. Photovoltaic Measurement. The current-voltage $(I-V)$ characteristics in the dark and under illumination were measured with a Keithley 2400 sourcemeter. The photocurrent was measured in a nitrogen-filled glove box under a solar simulator (Oriel $96000150 \mathrm{~W}$ ) with AM 1.5 G-filtered illumination $\left(100 \mathrm{~mW} \mathrm{~cm}^{-2}\right)$. The spectra-mismatch factor of the simulated solar irradiation was corrected using a Schott visible-color glass-filtered (KG5 color filter) Si diode (Hamamatsu S1133). The active area of the device was $0.25 \mathrm{~cm}^{2}$.

2.3. Dye Loading Measurement. The $\mathrm{TiO}_{2}$ films were put into the dye solution (N719, $3 \times 10^{-4} \mathrm{M}$ in tert-butanol and acetonitrile, $1: 1, \mathrm{v} / \mathrm{v}$ ) for $24 \mathrm{~h}$. Subsequently, the $\mathrm{TiO}_{2}$ films were washed with acetonitrile after the adsorption process and then dried in $\mathrm{N}_{2}$ flow. Dye loading measurements were conducted by desorbing the dye molecules from the dyeanchored films in $\mathrm{NaOH}$ ethanolic solution. The loading amount was calculated from the absorbance of the completely desorbed dye solutions by the spectrophotometer.

\subsection{Synthesis}

2.4.1. Synthesis of 2-(4-(4,4,5,5-Tetramethyl-1,3,2-dioxaborolane-2-yl)phenyl)-[1,2,4]triazolo[3,4-a]isoquinoline-3(2H)one (2). In a round-bottom flask, compound 1 (5.6 g, $16.3 \mathrm{mmol}$ ), 4,4,5,5-tetramethyl-2-(4,4,5,5-tetramethyl-1,3,2dioxaborolane-2-yl)-1,3,2-dioxaborolane $(4.4 \mathrm{~g}, 17.1 \mathrm{mmol})$, and potassium acetate $(4.8 \mathrm{~g}, 49.0 \mathrm{mmol})$ were dissolved in dimethyl sulfoxide (DMSO) under nitrogen atmosphere. After adding a catalyst of dichloro-[1,1'-bis(diphenylphosphino)ferrocenyl]palladium(II) $\left(\mathrm{Pd}(\mathrm{dppf}) \mathrm{Cl}_{2}\right)$, the mixed solution was heated at $80^{\circ} \mathrm{C}$ for 6 hours with vigorous stirring. It was then poured into EtOAc-water for extraction. The organic phase was concentrated and adsorbed on silica gel and purified by column chromatography using hexane/EtOAc mixture $(5: 1)$ as the eluant: white powder; yield $5.32 \mathrm{~g}(84.2 \%) ;{ }^{1} \mathrm{H}$ NMR $\left(300 \mathrm{MHz}, \mathrm{d}_{6}\right.$-DMSO): $\delta 8.31$ $(\mathrm{d}, 1 \mathrm{H}, J=7.53 \mathrm{~Hz}), 8.17(\mathrm{~d}, 2 \mathrm{H}, J=8.23 \mathrm{~Hz}), 7.84(\mathrm{~d}, 3 \mathrm{H}$, $J=8.57 \mathrm{~Hz}), 7.77 \sim 7.66(\mathrm{~m}, 3 \mathrm{H}), 7.02(\mathrm{~d}, 1 \mathrm{H}, J=7.44 \mathrm{~Hz}), 1.32$ $(\mathrm{s}, 12 \mathrm{H})$.

2.4.2. Synthesis of 5-(4-(3-Oxo-[1,2,4]triazolo[3,4-a]isoquinoline-2(3H)-yl)phenyl)thiophene-2-carbaldehyde (3). In a three-necked round-bottomed flask $(25 \mathrm{~mL})$ equipped with a reflux condenser, compound $2(1.71 \mathrm{~g}, 4.4 \mathrm{mmol}), 5-$ bromothiophene-2-carbaldehyde ( $1.0 \mathrm{~g}, 5.2 \mathrm{mmol})$, and $2 \mathrm{M}$ potassium carbonate solution were added to a suspension of $\mathrm{Pd}\left(\mathrm{PPh}_{3}\right)_{4}(3.0 \mathrm{~mol} \%)$ in tetrahydrofuran $(30 \mathrm{~mL})$ at ambient temperature under nitrogen. The reaction mixture was heated to $80^{\circ} \mathrm{C}$ with rapid stirring for 16 hours. After cooling, the resulting solution was poured into water. The separated solid was filtered and thoroughly washed with water-acetone and dried: pale yellow powder; yield $1.0 \mathrm{~g}$ (61.6\%); ${ }^{1} \mathrm{H}$ NMR (300 MHz, $\mathrm{d}_{6}$-DMSO): $\delta 9.23(\mathrm{~s}, 1 \mathrm{H}), 8.32$ $(\mathrm{d}, 1 \mathrm{H}, J=7.56 \mathrm{~Hz}), 8.24(\mathrm{~d}, 2 \mathrm{H}, J=8.53 \mathrm{~Hz}), 8.07(\mathrm{~d}, 1 \mathrm{H}$, $J=3.81 \mathrm{~Hz}), 8.01(\mathrm{~d}, 2 \mathrm{H}, J=8.60 \mathrm{~Hz}), 7.86 \sim 7.67(\mathrm{~m}, 5 \mathrm{H})$, $7.04(\mathrm{~d}, 1 \mathrm{H}, J=7.39 \mathrm{~Hz})$.

2.4.3. Synthesis of 2-Cyano-3-(5-(4-(3-oxo-[1,2,4]triazolo[3,4a]isoquinoline-2(3H)-yl)phenyl)thiophene-2-yl)acrylic Acid (4L). In a three-neck bottle, compound $3(1.2 \mathrm{~g}, 3.3 \mathrm{mmol})$, 2-cyanoacetic acid $(0.6 \mathrm{~g}, 6.5 \mathrm{mmol})$, and piperidine $(0.08 \mathrm{~g}$, $0.98 \mathrm{mmol}$ ) were dissolved in chloroform. The mixed solution was refluxed for 16 hours with rapid stirring. After cooling, the resulting solution was poured into EtOAc- $\mathrm{MeOH}$. The separated solid was filtered and thoroughly washed with EtOAc and $\mathrm{MeOH}$ and dried: pale orange powder; yield $1.2 \mathrm{~g}(85.0 \%) ;{ }^{1} \mathrm{H}$ NMR $\left(300 \mathrm{MHz}, \mathrm{d}_{6}\right.$-DMSO): $\delta 8.32(\mathrm{~d}, 1 \mathrm{H}$, $J=7.50 \mathrm{~Hz}), 8.23(\mathrm{~s}, 1 \mathrm{H}), 8.20(\mathrm{~d}, 2 \mathrm{H}, J=3.20 \mathrm{~Hz}), 7.93(\mathrm{~d}$, $2 \mathrm{H}, J=8.72 \mathrm{~Hz}), 7.89 \sim 7.67(\mathrm{~m}, 6 \mathrm{H}), 7.03(\mathrm{~d}, 1 \mathrm{H}, J=7.46 \mathrm{~Hz})$; ESI-MS $m / z 437\left(\mathrm{M}-\mathrm{H}^{+}\right)$; Anal. Calcd for $\mathrm{C}_{24} \mathrm{H}_{14} \mathrm{~N}_{4} \mathrm{O}_{3} \mathrm{~S}$ : C, 65.74; H, 3.22; N, 12.78. Found: C, 65.96; H, 3.28; N, 12.60 .

\section{Results and Discussion}

3.1. Synthesis. The synthetic route of the co-adsorbent is shown in Figure 1. 2-(4-bromophenyl)- $[1,2,4]$ triazolo[3,4a] isoquinoline-3(2H)-one (1) was obtained as reported earlier 
<smiles>O=c1n(-c2ccc(Br)cc2)nc2c3ccccc3ccn12</smiles>

1<smiles>N#C/C(=C/c1ccc(-c2ccc(-n3nc4c5ccccc5ccn4c3=O)cc2)s1)C(=O)O</smiles>

$4 \mathrm{~L}$
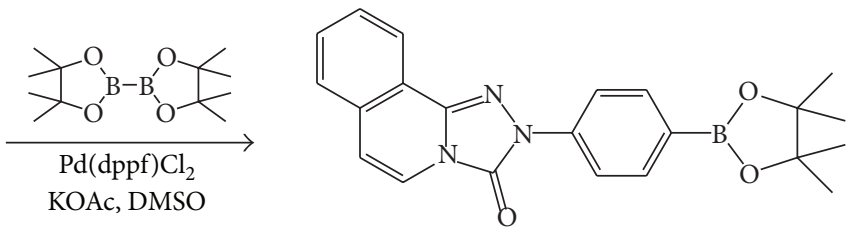

$\mathrm{Pd}\left(\mathrm{PPh}_{3}\right)_{4}$
$\mathrm{~K}_{2} \mathrm{CO}_{3}$
$\mathrm{THF}$

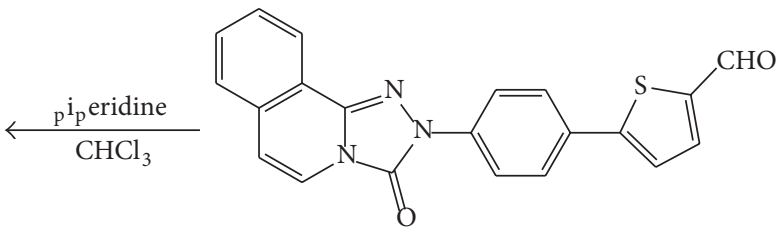

3

FIGURE 1: Synthetic route of co-adsorbent $4 \mathrm{~L}$.

[16]. $4 \mathrm{~L}$ was synthesized by Suzuki coupling of compound 2 with 5 -formylthiophene-2-ylboronic acid, followed by Knoevenagel condensation reaction with cyanoacrylic acid in the presence of piperidine. This product was well characterized by spectroscopic analyses.

3.2. The Double-Layer $\mathrm{TiO}_{2}$ Film. Recently, an enhancement in light absorption via application of light scattering has been studied for DSSCs $[17,18]$. To take advantage of the light-scattering effect of $\mathrm{TiO}_{2}$ particles, light absorption can be enhanced in $\mathrm{TiO}_{2}$ films by increasing the absorption path length of photons, which can effectively improve the photocurrent output of cells. In order to obtain a high photoelectric conversion efficiency in DSSCs, a double-layer $\mathrm{TiO}_{2}$ film was fabricated, composed of a light-scattering layer and a transparent layer. The transparent layer was prepared by commercial $\mathrm{TiO}_{2}$ paste and the light-scattering layer was deposited by home-made scattering $\mathrm{TiO}_{2}$ paste. First, $\mathrm{TiCl}_{4}$ solution was converted to $\mathrm{Ti}(\mathrm{OH})_{4}$ gel after ammonia neutralization and $\mathrm{H}_{2} \mathrm{O}_{2}$ was used to hydrolyze $\mathrm{Ti}(\mathrm{OH})_{4}$ to form $\mathrm{TiO}_{2}$ sol. Subsequently, the result solution was refluxed 35-40 hours for crystallization, and the anatase type $\mathrm{TiO}_{2}$ organic sol was obtained. This solution was concentrated by rotary evaporator and dispersed in $\alpha$-terpineol with ethyl cellulose for scattering $\mathrm{TiO}_{2}$ paste. After screen-printing, the thickness of the double-layer film was about $16 \mu \mathrm{m}$. Figure 2 (a) shows the surface morphology of the light-scattering layer, revealing their well-connected network and the porous nature of $\mathrm{TiO}_{2}$ film. The average sizes of the nanostructures were about $100 \mathrm{~nm}$ in diameter. This results in a good scattering effect because of the elongated optical path length. Figure 2(b) shows the surface morphology of light-scattering layer after $\mathrm{TiCl}_{4}$ posttreatment. From the SEM image, one can see that
TABle 1: The amount of adsorbed N719 dye for different $\mathrm{TiO}_{2}$ structures.

\begin{tabular}{|c|c|c|}
\hline & $\mathrm{TiO}_{2}$ structure & $\begin{array}{l}\text { Dye adsorption } \\
\left(10^{-7} \mathrm{~mol} \mathrm{~cm}^{-2}\right)\end{array}$ \\
\hline Film 1 & FTO/transparent layer & 5.23 \\
\hline Film 2 & $\begin{array}{c}\mathrm{FTO} / \text { transparent layer/light-scattering } \\
\text { layer }\end{array}$ & 5.35 \\
\hline Film 3 & $\begin{array}{l}\mathrm{FTO} / \text { transparent layer/light-scattering } \\
\text { layer/TiCl }{ }_{4} \text { posttreatment }\end{array}$ & 7.02 \\
\hline
\end{tabular}

the necking of the $\mathrm{TiO}_{2}$ particles and the surface roughness are enhanced and resulting in higher dye adsorption amount. As summarized in Table 1, it was found that the dye amount on a film of Film $3-\mathrm{TiCl}_{4}$ posttreatment is higher than those of Films 1 and 2. It is well known that the shortcircuit current density is mainly determined by the initial number of photogenerated electrons, and the initial number of photogenerated electrons could be significantly affected by the dye amount on the $\mathrm{TiO}_{2}$ films. This result agrees well with recent experiments $[19,20]$. In order to maximize the light harvesting efficiency, we fabricate the structure of Film 3 for the follow-up discussion of co-adsorbent effect.

3.3. The Concentration Effect of Coadsorbents. After optimization of the devices, the photovoltaic characteristics of the small molecule as co-adsorbent for DSSCs were evaluated with a sandwich DSSC cell (as shown in Figure 3) using $0.6 \mathrm{M}[\mathrm{BMI}][\mathrm{I}], 0.1 \mathrm{M}$ GuNCS, $0.3 \mathrm{M} \mathrm{I}_{2}$, and $0.5 \mathrm{M} \mathrm{TBP}$ in a $\mathrm{AN} / \mathrm{VN}(85 / 15, \mathrm{v} / \mathrm{v})$ solvent as the redox electrolyte. Details of the device preparation and characterization are described in the experimental section, and all the essential properties of these cells are listed in Figure 3 and Table 2. 


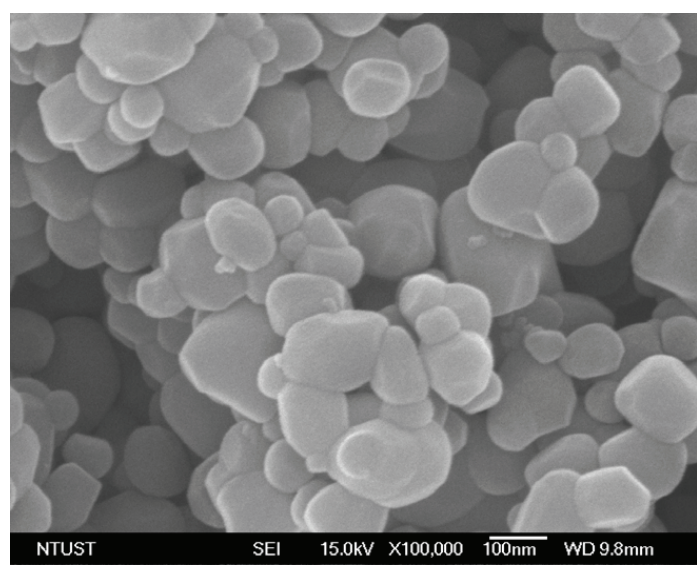

(a)

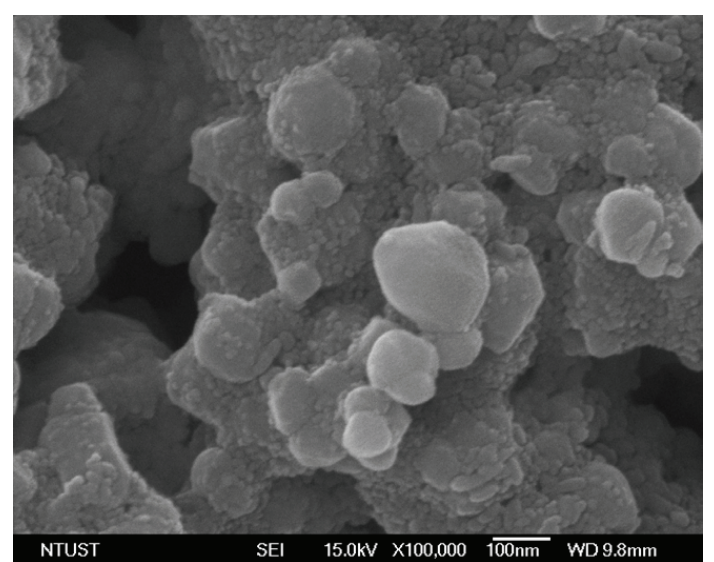

(b)

FIGURE 2: SEM images of (a) light-scattering layer of double layer $\mathrm{TiO}_{2}$ films and (b) $\mathrm{TiCl}_{4}$ posttreatment of light-scattering layer.

TABLE 2: Photovoltaic parameters of the DSSCs with N719: $4 \mathrm{~L}$ in different molar ratios under AM $1.5 \mathrm{G}$ sunlight $\mathrm{t}^{\mathrm{a}}$.

\begin{tabular}{|c|c|c|c|c|c|}
\hline & $\begin{array}{l}\text { Dyestuff coadsorbent } \\
\text { molar ratio }\end{array}$ & $J_{\mathrm{sc}}\left(\mathrm{mA} \mathrm{cm}^{-2}\right)$ & $V_{\mathrm{oc}}(\mathrm{V})$ & $\mathrm{FF}$ & $\eta(\%)$ \\
\hline Device A & N719 & 15.65 & 0.76 & 0.70 & 8.36 \\
\hline Device B & $\begin{array}{l}\mathrm{N} 719-4 \mathrm{~L} \\
1: 0.25\end{array}$ & 16.39 & 0.77 & 0.70 & 8.83 \\
\hline Device C & $\begin{array}{l}\text { N719-4L } \\
1: 0.50\end{array}$ & 15.27 & 0.76 & 0.71 & 8.21 \\
\hline Device D & $\begin{array}{c}\text { N719-4L } \\
1: 1\end{array}$ & 15.72 & 0.75 & 0.69 & 8.10 \\
\hline
\end{tabular}

${ }^{\mathrm{a}}$ Performances of DSSCs were measured with $0.25 \mathrm{~cm}^{2}$ working area.

Under the standard AM 1.5 G irradiation, the maximum efficiency $(\eta)$ for the N719-sensitized solar cell-device B with an active area of $0.25 \mathrm{~cm}^{2}$ was calculated to be $8.36 \%$, with a $J_{\mathrm{sc}}$ of $15.65 \mathrm{~mA} \mathrm{~cm}^{-2}$, a $V_{\text {oc }}$ of $0.76 \mathrm{~V}$, and a fill factor (FF) of 0.70 . However, the solar cells based on the $12+4 \mu \mathrm{m}$ transparent layer which was sensitized by N719-4L with 1 to 0.25 molar ratio yielded a remarkably high photocurrent density of $16.39 \mathrm{~mA} \mathrm{~cm}^{-2}$, an open circuit voltage of $0.77 \mathrm{~V}$, and a fill factor of 0.70 , corresponding to an overall power conversion efficiency of $8.83 \%$. This result is also in agreement with the observation of the incident photon-to-electron conversion efficiency (IPCE) action spectra of DSSCs presented in Figure 4. With the increase in $4 \mathrm{~L}$ concentration, the overall power conversion efficiency shows a downward trend. Compared to device A with a single dyestuff-N719, devices $\mathrm{C}$ and $\mathrm{D}$ based on a high $4 \mathrm{~L}$ molar ratio exhibit lower $\eta$ values of $8.21 \%$ and $8.10 \%$. It is well known that co-adsorbents will compete with $\mathrm{N} 719$ for adsorption on the $\mathrm{TiO}_{2}$ surface. This result shows that N719 and co-adsorbent $4 \mathrm{~L}$ are in balance at a 1 to 0.25 molar ratio. In this concentration of cosensitizers, N719 may occupy positions on the $\mathrm{TiO}_{2}$ surface, and coadsorbent $4 \mathrm{~L}$ then anchors to the blank to create a perfect insulating molecular layer. Because of this layer, the charge recombination process can be shielded, and the incident photo-to-electron conversion efficiency can be enhanced, and this increases $V_{\mathrm{oc}}, J_{\mathrm{sc}}$, and $\eta$. On the other hand, devices $\mathrm{C}$ and $\mathrm{D}$ show downward trend at $V_{\mathrm{oc}}$ and $\mathrm{FF}$ values in comparison with device $\mathrm{A}$. This indicates that coadsorbent $4 \mathrm{~L}$ has considerable superiority at 1 to 0.50 and 1 to 1 molar ratios, with some N719 molecules having lost their positions on $\mathrm{TiO}_{2}$ and being replaced by co-adsorbent $4 \mathrm{~L}$. This increases the opportunities for $\pi-\pi$ stacking of small organic molecule-4L and decreases the contribution of N719 to the incident photon-to-electron conversion efficiency [2022]. These photovoltaic performance results indicate that coadsorption with 4L and N719 in an appropriate concentration is effective in improving solar cell performance.

\section{Conclusions}

A new triazoloisoquinoline-based co-adsorbent has been prepared and applied in DSSC. This study demonstrates that coadsorption of N719 sensitizer with triazoloisoquinolinebased organic small molecule onto nanocrystalline $\mathrm{TiO}_{2}$ films significantly increases the photovoltage and photocurrent, thus enhancing the total conversion efficiency. After optimization of the structure of the $\mathrm{TiO}_{2}$ layer, the cell produced in this work achieved an energy conversion efficiency as high as $8.83 \%$ at $100 \mathrm{~mW} \mathrm{~cm}^{-2}$ and AM $1.5 \mathrm{G}$ at 1 to 0.25 (N719: co-adsorbent) molar ratio. This improved conversion efficiency is attributed to the insulating molecular layer, which was composed of small molecule 4L and N719, 


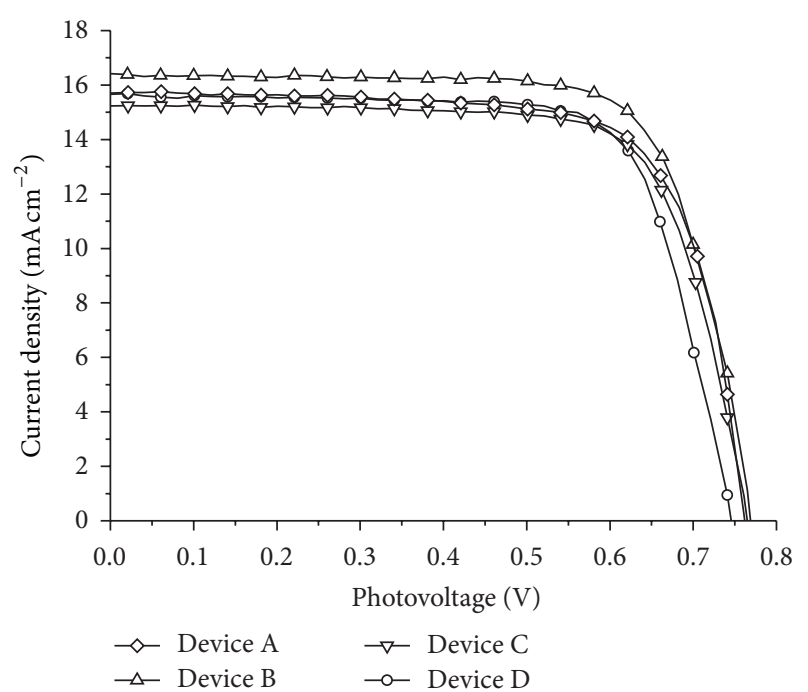

FIGURE 3: Photocurrent density-voltage characteristics of solar cells sensitized by N719 (Device A), N719:4L (1:0.25) (Device B), N719: 4L (1:0.5) (Device C), and N719:4L (1:1) (Device D) with $12.0+4.0 \mu \mathrm{m}$ double layers nanocrystalline $\mathrm{TiO}_{2}$ electrodes.

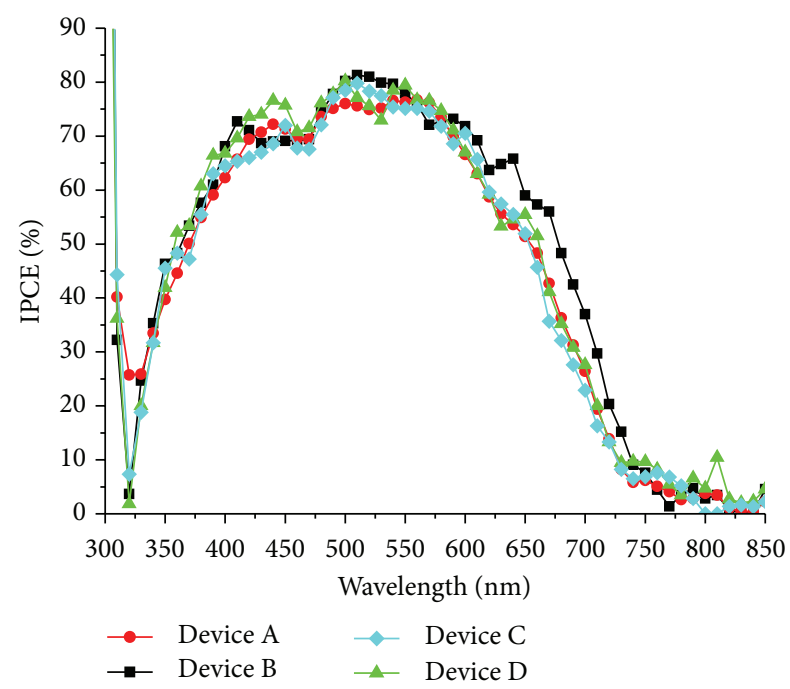

FIGURE 4: IPCE action spectra of solar cells sensitized by N719 (Device A), N719: 4L (1:0.25) (Device B), N719: 4L (1:0.5) (Device C), and N719: 4L (1:1) (Device D) with $12.0+4.0 \mu \mathrm{m}$ double layers nanocrystalline $\mathrm{TiO}_{2}$ electrodes.

and the charge recombination process can be shielded. This breakthrough will contribute to promoting organic small molecule as co-adsorbents in DSSC.

\section{References}

[1] B. O’Regan and M. Grätzel, "A low-cost, high-efficiency solar cell based on dye-sensitized colloidal $\mathrm{TiO}_{2}$ films," Nature, vol. 353, no. 6346, pp. 737-740, 1991.

[2] M. Gratzel, "Conversion of sunlight to electric power by nanocrystalline dye-sensitized solar cells," Journal of Photochemistry and Photobiology A, vol. 164, pp. 3-14, 2004.
[3] J. N. de Freitas, A. F. Nogueira, and M.-A. de Paoli, "New insights into dye-sensitized solar cells with polymer electrolytes," Journal of Materials Chemistry, vol. 19, no. 30, pp. 5279-5294, 2009.

[4] M. Gorlov and L. Kloo, "Ionic liquid electrolytes for dyesensitized solar cells," Dalton Transactions, no. 20, pp. 26552666, 2008.

[5] B. Li, L. Wang, B. Kang, P. Wang, and Y. Qiu, "Review of recent progress in solid-state dye-sensitized solar cells," Solar Energy Materials and Solar Cells, vol. 90, no. 5, pp. 549-573, 2006.

[6] M. K. Nazeeruddin, A. Kay, I. Rodicio, and M. Gratzel, "Conversion of light to electricity by cis- $\mathrm{X}_{2}$ bis $\left(2,2^{\prime}\right.$-bipyridyl$4,4^{\prime}$-dicarboxylate)ruthenium(II) charge-transfer sensitizers (X $=\mathrm{Cl}^{-}, \mathrm{Br}^{-}, \mathrm{I}^{-}, \mathrm{CN}^{-}$, and $\mathrm{SCN}^{-}$) on nanocrystalline $\mathrm{TiO}_{2}$ electrodes," Journal of the American Chemical Society, vol. 115, no. 14, pp. 6382-6390, 1993.

[7] H. Paulsson, A. Hagfeldt, and L. Kloo, "Molten and solid trialkylsulfonium iodides and their polyiodides as electrolytes in dye-sensitized nanocrystalline solar cells," Journal of Physical Chemistry B, vol. 107, no. 49, pp. 13665-13670, 2003.

[8] J.-H. Yum, P. Walter, S. Huber et al., "Efficient far red sensitization of nanocrystalline $\mathrm{TiO}_{2}$ films by an unsymmetrical squaraine dye," Journal of the American Chemical Society, vol. 129, no. 34, pp. 10320-10321, 2007.

[9] H. Tian, X. Yang, J. Cong et al., "Tuning of phenoxazine chromophores for efficient organic dye-sensitized solar cells," Chemical Communications, no. 41, pp. 6288-6290, 2009.

[10] S. Ito, H. Miura, S. Uchida et al., "High-conversion-efficiency organic dye-sensitized solar cells with a novel indoline dye," Chemical Communications, no. 41, pp. 5194-5196, 2008.

[11] J.-C. Chang, C.-H. Yang, H.-H. Yang et al., "Pyridinium molten salts as co-adsorbents in dye-sensitized solar cells," Solar Energy, vol. 85, no. 1, pp. 174-179, 2011.

[12] H. Kusama and H. Arakawa, "Influence of pyrimidine additives in electrolytic solution on dye-sensitized solar cell," Journal of Photochemistry and Photobiology A, vol. 160, no. 3, pp. 171-179, 2003.

[13] S. Ruhle, M. Greenshtein, S.-G. Chen et al., "Molecular adjustment of the electronic properties of nanoporous electrodes in dye-sensitized solar cells," Journal of Physical Chemistry B, vol. 109, no. 40, pp. 18907-18913, 2005.

[14] M. Wang, C. Gratzel, S.-J. Moon et al., "Surface design in solid-state dye sensitized solar cells: effects of zwitterionic coadsorbents on photovoltaic performance," Advanced Functional Materials, vol. 19, no. 13, pp. 2163-2172, 2009.

[15] Y. M. Lin, S. L. Liu, and Y. H. Tseng, "Photocatalytic titanium oxide solution and method for producing the same," TW I30690, 2005.

[16] C. Y. Chiu, C. N. Kuo, W. F. Kuo, and M. Y. Yeh, "Studies on the reaction of $\alpha$-chlororformylarylhydrazine hydrochloride with N-heterocyclic comounds," Journal of the Chinese Chemical Society, vol. 49, p. 239, 2002.

[17] S. Hore, C. Vetter, R. Kern, H. Smit, and A. Hinsch, "Influence of scattering layers on efficiency of dye-sensitized solar cells," Solar Energy Materials and Solar Cells, vol. 90, no. 9, pp. 11761188, 2006.

[18] S. Ito, T. N. Murakami, P. Comte et al., "Fabrication of thin film dye sensitized solar cells with solar to electric power conversion efficiency over 10\%," Thin Solid Films, vol. 516, no. 14, pp. 46134619, 2008. 
[19] P. M. Sommeling, B. C. O’Regan, R. R. Haswell et al., "Influence of a $\mathrm{TiCl}_{4}$ post-treatment on nanocrystalline $\mathrm{TiO}_{2}$ films in dyesensitized solar cells," Journal of Physical Chemistry B, vol. 110, no. 39, pp. 19191-19197, 2006.

[20] M.-S. Wu, C.-H. Tsai, J.-J. Jow, and T.-C. Wei, "Enhanced performance of dye-sensitized solar cell via surface modification of mesoporous $\mathrm{TiO}_{2}$ photoanode with electrodeposited thin $\mathrm{TiO}_{2}$ layer," Electrochimica Acta, vol. 56, no. 24, pp. 8906-8911, 2011.

[21] X.-F. Wang, H. Tamiaki, L. Wang et al., "Chlorophyll-a derivatives with various hydrocarbon ester groups for efficient dyesensitized solar cells: static and ultrafast evaluations on electron injection and charge collection processes," Langmuir, vol. 26, no. 9, pp. 6320-6327, 2010.

[22] F. Gao, Y. Cheng, Q. Yu et al., "Conjugation of selenophene with bipyridine for a high molar extinction coefficient sensitizer in dye-sensitized solar cells," Inorganic Chemistry, vol. 48, no. 6, pp. 2664-2669, 2009. 

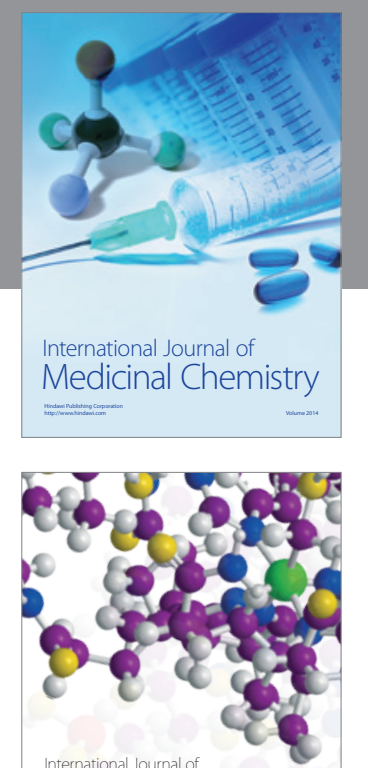

\section{Carbohydrate} Chemistry

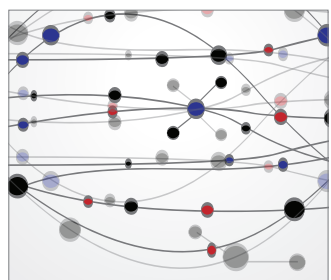

The Scientific World Journal
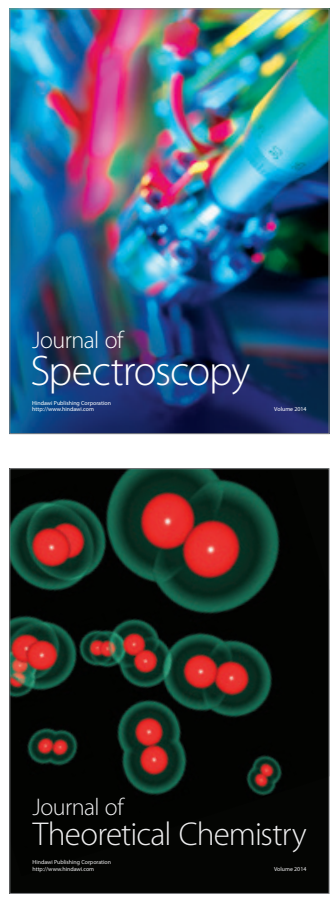
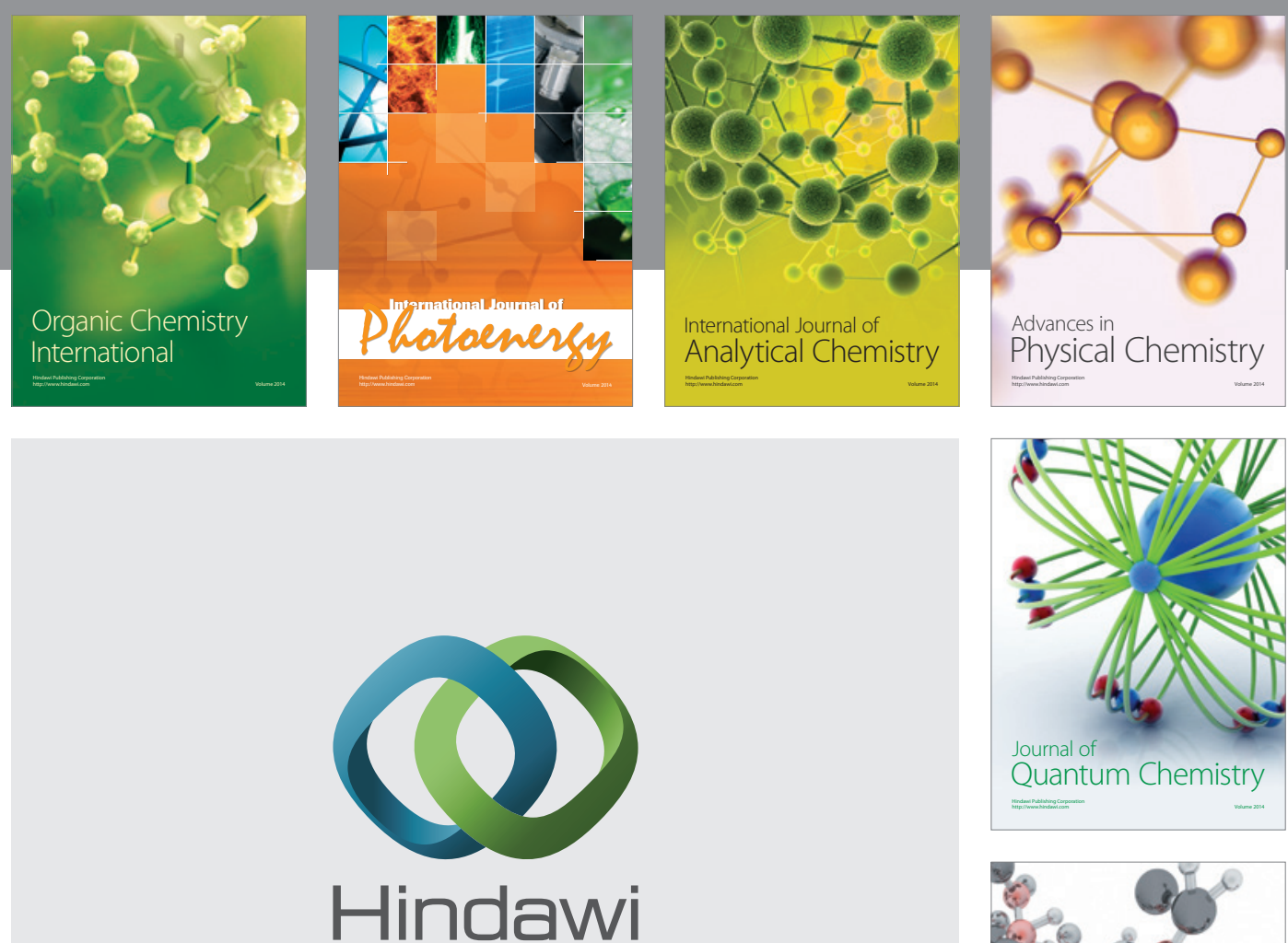

Submit your manuscripts at

http://www.hindawi.com

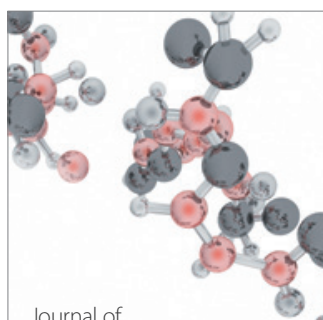

Analytical Methods

in Chemistry

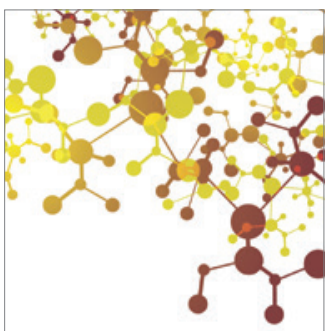

Journal of

Applied Chemistry

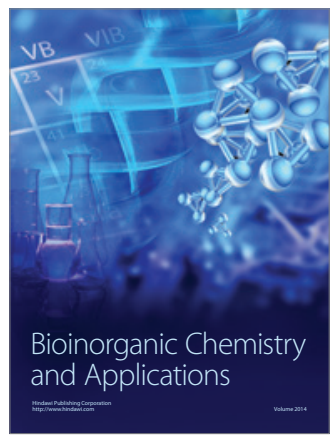

Inorganic Chemistry
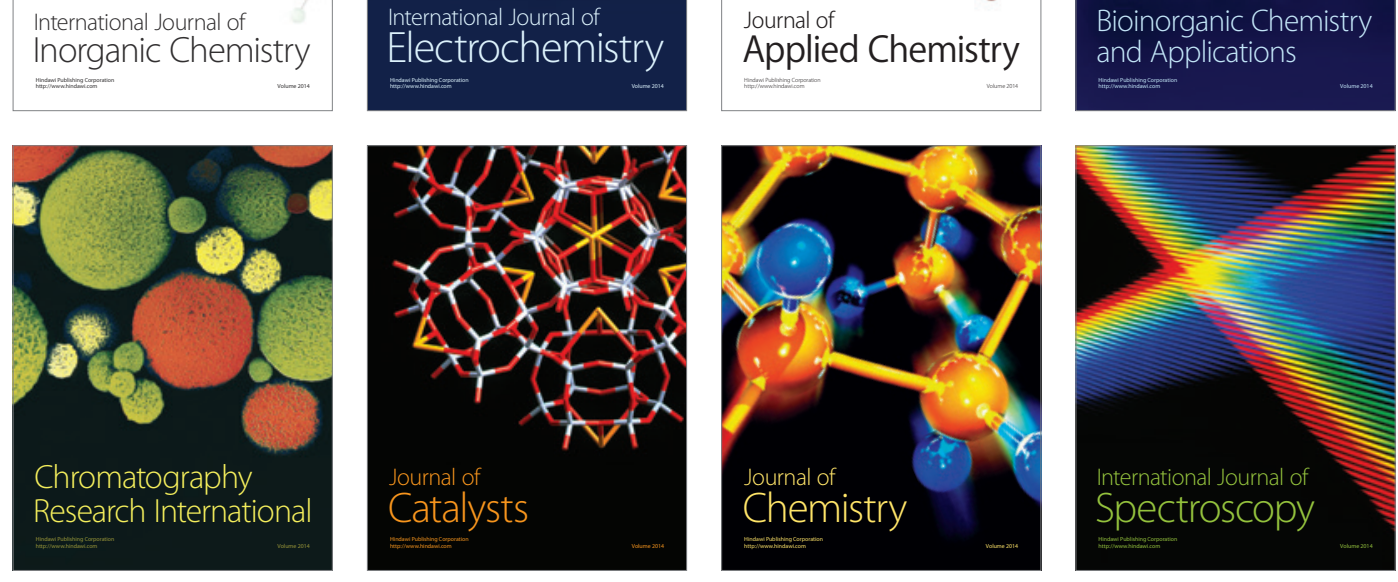